OPINIÃO

OPINION

\section{A indústria de inovação em saúde $e$ a mídia: preconceitos e desafios}

\author{
The innovative industry in health and the \\ media: prejudgements and challenges \\ Octávio Nunes \\ DOI: 10.21115/JBES.v9.suppl1.111-114
}

Quando centenas de ativistas protetores dos animais, dentre eles algumas celebridades da TV, invadiram o laboratório do Instituto Royal no interior de São Paulo em outubro de 2013, eles estavam movidos por uma causa que Ihes parecia justa e, ao mesmo tempo, convictos de que uma ação radical seria a única forma de mobilizar, ter apoio da mídia e sensibilizar a sociedade brasileira.

A atitude teria sido planejada antecipadamente, até mesmo na forma. À força, interromperam as atividades de técnicos e cientistas, retiraram das dependências dos laboratórios camundongos e coelhos, mas a principal motivação foi a busca por cães da raça beagle, sujeitos de pesquisa no laboratório que estariam, segundo presumiram os invasores, sendo maltratados em experimentos científicos.

À época, o Instituto Royal alegou seguir os protocolos de ensaios clínicos que estavam sendo desenvolvidos ali devidamente legalizados e, em muitos casos, financiados com dinheiro público por meio de organismos de fomento à pesquisa e à inovação. O uso de animais em estudos clínicos é regulamentado no Brasil, autorizado pelos órgãos sanitário e de ética em pesquisa. Alegações de que "existem testes in vitro que poderiam descartar o uso de seres vivos em ensaios" clínicos não levam em conta o fato de que tais testes representam apenas uma pequena parte dos processos investigatórios exigidos pela regulação sanitária mundial. Acima de tudo, são imprescindíveis para o bem das populações humanas, potenciais usuárias que, de outra forma, seriam expostas a riscos desconhecidos e sem controle.

Após a invasão, médicos, veterinários, biólogos, biomédicos e outros profissionais altamente qualificados foram demitidos, as atividades de pesquisa encerradas e, quatro anos depois do episódio, o prédio do Instituto Royal, em São Roque, está abandonado.

Alguns veículos trataram a invasão como sendo um "resgate" dos animais partindo do pressuposto de que antes teria havido um "sequestro". O tratamento dado nos textos das matérias publicadas reforçou a ideia de que a ação de invadir um laboratório teria sido providencial e justa, portanto, necessária. Os ativistas alcançaram o que pretendiam: obtiveram claramente o apoio da imprensa, que supervalorizou a ocorrência por meio de uma mensagem subliminar, segundo a qual o grupo estaria agindo em nome do bem comum, da coletividade. Entretanto, o essencial, a suposta conduta dos investigadores científicos de maltratar os animais, até hoje, não foi comprovado.

Inúmeros são os exemplos em que a prática jornalística cede lugar à parcialidade quando o agente da notícia tende, por vezes involuntariamente, a julgar com o objetivo de "promover a justiça social", ainda que se esforce para ouvir todos os lados envolvidos na questão, uma das cláusulas pétreas dos princípios fundamentais do jornalismo.

Em 2016, o Senado Federal brasileiro aprovou a liberação do uso da fosfoetanolamina sintética para pacientes com câncer, uma substância que teria sido desenvolvida no Instituto de Química da Universidade de São Paulo, em São Carlos, no interior, e que prometia curar o câncer, sem especificar o tipo.

Quando o uso da "pílula do câncer" foi aprovado, não havia estudos científicos que pudessem comprovar sua eficácia e segurança. Mas uma parte importante e influente da mídia reproduziu enfaticamente o discurso dos parlamentares que defendiam a liberação da tal substância. Convencida de que a pílula não seria apenas uma alternativa terapêutica, mas uma oportunidade de o País exercer uma suposta soberania em relação à dependência das pesquisas das indústrias farmacêuticas globais, divulgou que a comprovação viria depois, por meio de estudos a serem desenvolvimentos em laboratórios oficiais. Os estudos começaram a ser feitos, mas a substância não se mostrou eficaz nem segura ainda nas fases iniciais dos testes, como previam cientistas e entidades não governamentais favoráveis a regras mais claras e seguras para pesquisas clínicas no Brasil.

Recebido em: 31/07/2017 Aprovado para publicação em: 21/08/2017

1. Jornalista e Diretor da Interfarma - Associação da Indústria Farmacêutica de Pesquisa, São Paulo, SP, Brasil.

Autor correspondente: Octávio Nunes. Rua Verbo Divino, 1488 - 70 Andar - SL 7A, Chácara Santo Antonio, São Paulo, SP, Brasil. CEP: 04719-904. Telefone: +55 (11) 5180-3475

E-mail: octavio.nunes@interfarma.org.br 
A supervalorização midiática não impediu que o caso da fosfoetanolamina caísse no esquecimento, mas, à época, a sociedade foi levada a acreditar no improvável: que algum laboratório pudesse produzir, em tempo recorde, pesquisas em fase pré-clínica e em três outras importantes e decisivas fases do processo que, em condições normais, levaria anos para ser concluído. E em meio à comoção, leitores, espectadores e ouvintes deixaram de ser informados pela imprensa de um dado essencial, o de que a responsabilidade de aprovar a liberação do uso de uma substância no Brasil é da Anvisa, a Agência sanitária nacional, e não do Parlamento.

A abordagem na cobertura de eventos como esses remete à consagrada fórmula do jornalismo moderno de ressaltar "empatia e drama", que é a capacidade que o espectador tem de compreender o sentimento do personagem central da matéria, se identificar e se colocar no lugar dele; no caso anteriormente citado, de pacientes brasileiros com câncer.

Infalível no conceito, pois envolve, toca, sensibiliza e mexe com o estado de espírito do espectador ou leitor, a fórmula falha no pragmatismo, quando sonega uma informação útil, relevante ao consumidor, por erro de apuração da notícia, falta de afinidade com o assunto, desconhecimento, ausência de especialização ou simplesmente por convicções direcionadoras do jornalista, sejam elas políticas, de interesse pessoal ou ideológicas.

Muitos fatores podem explicar a produção de um jornalismo de espetáculo, mas uma causa é perfeitamente aceitável em sua quase plenitude: a concorrência inescapável e, ao mesmo tempo, desleal e predatória das mídias sociais. Isentas de responsabilização e infinitamente mais ágeis, impõem ao jornalismo contemporâneo uma espécie de caminho do vale das sombras. Os meios de comunicação de massa que produzem conteúdo de verdade precisam de agilidade tanto quanto as mídias sociais, mas não podem ser irresponsáveis, imprecisos nem suficientemente imaginativos a ponto de falsear os fatos.

A propósito, está em curso a formação de uma indústria de produção de notícias falsas, as chamadas fake news, cujo objetivo é enganar o público e que, na maioria das vezes, está a serviço de algum interesse específico. Há, de outro lado, um consumo desenfreado por esse tipo de produto, especialmente nas plataformas digitais, labirinto indecifrável e sem controle que vem sendo usado, pelo menos no conceito, por figuras do cenário político mundial como uma forma de confrontar a credibilidade de veículos de comunicação influentes e respeitados.

O presidente norte-americano, Donald Trump, frequentemente usa o argumento dos riscos provocados pela chamada fake news para tentar desqualificar notícias a respeito da sua administração. O propósito é, claramente, confundir o público e demonstrar que uma coisa é o fato, outra é a versão. Para Trump, a versão é mais importante que o fato, um neologis- mo que ganhou o singelo nome de pós-verdade. Seu primogênito, que leva o seu nome e é mais conhecido como Don Jr., reforça as teses do pai ao atacar os críticos da imprensa. A rede de TV norte-americana CNN é alvo preferido. "Eles sempre serão número 1 em notícias falsas" - diz Don Jr.

As notícias falsas ganharam destaque na agenda de discussões da reunião da Associação Norte-americana para o Progresso da Ciência, ocorrida no início de 2017, em Boston. A preocupação faz sentido, pois as fake news vêm ganhando espaço nos meios de comunicação e muitas vezes não aparecem apenas como notícia falsa, inventada, no formato de hard news, mas em forma de estelionato intelectual com gravíssimas consequências para a reputação dos meios de informação e para a sociedade.

Em 1998, a revista The Lancet publicou um estudo do médico britânico Andrew Wakefield, segundo o qual oito de doze crianças analisadas em sua pesquisa teriam manifestado sintomas de autismo depois de terem tomado a vacina tríplice viral. Mais tarde, descobriu-se que não se tratava propriamente de um "alerta científico" e sim de interesses de advogados dispostos a processar a indústria farmacêutica. A própria revista retirou o estudo de seu site e o médico perdeu o registro profissional, mas, apesar dessas medidas, o movimento antivacinas emergiu nas redes sociais e continua ganhando adeptos na Europa e nos Estados Unidos, regiões responsáveis pelo ressurgimento de surtos de sarampo, e também no Brasil.

No caso do Brasil, situações como essa podem ganhar dimensões extraordinárias se não houver, por parte da imprensa, um equilíbrio na cobertura dos fatos, já que o País registra o maior índice de confiança na mídia no mundo. Pesquisa recente do Instituto Reuters para o Estudo do Jornalismo, da quase milenar Universidade de Oxford, na Inglaterra, revela que $60 \%$ dos brasileiros confiam nas notícias veiculadas pelas empresas de comunicação - atrás apenas da Finlândia, com $62 \%$. Significa dizer que qualquer coisa que se publique na imprensa certamente terá repercussão. A confiança também é alta em países como Portugal, Polônia e Holanda. A média dos países pesquisados é de $43 \%$. A pesquisa ouviu 70 mil entrevistados em 36 países.

O jornalista especializado Gary Schwitzer, Professor da Universidade de Minnesota - Escola de Saúde Pública e Escola de Jornalismo - e Publisher da HealthNewsReview.org cujo portal tem o sugestivo slogan "Your health news watchdog", algo como "seu cão de guarda da notícia de saúde", afirma que "os jornalistas têm uma responsabilidade especial na cobertura de notícias médicas e de saúde". "Sabem que leitores e telespectadores podem tomar importantes decisões de cuidados de saúde com base nas informações fornecidas em nossas histórias."

Schwitzer foi um dos jornalistas de saúde convidados da revista científica PloS Medicine para participar de um deba- 
te sobre a polêmica envolvendo, em 2004, tabloides norte-americanos que divulgaram notícias sugerindo que os efeitos colaterais de um medicamento antirretroviral administrado durante a gestação teriam zerado na transmissão do HIV de mãe para o filho. Especialistas não acreditaram na história e a polêmica se instalou. A publicação decidiu, então, abrir um debate e pediu que alguns jornalistas reconhecidos na cobertura de saúde e ciência pudessem dar a sua opinião sobre os limites da responsabilidade do jornalista ao divulgar uma notícia e o impacto disso na vida e no cotidiano das pessoas.

Gary Schwitzer sempre foi um defensor da tese de que jornalistas especializados deveriam assinar uma "declaração de princípios" na cobertura setorial de saúde, ciência e inovação e levou a ideia à Associação Norte-americana de Jornalistas Especializados em Saúde. A associação existe para troca de informações e experiência entre os profissionais, mas tem como papel fundamental melhorar a qualidade da cobertura de saúde com base em preceitos éticos.

As afirmações no campo da ciência, até mesmo para os iniciados na avaliação de tecnologias em saúde, estão às vezes sujeitas a diferentes interpretações, mesmo quando nos referimos a uma metodologia, por mais exata e precisa que possa parecer. A compreensão de um fato requer conhecer os métodos do estudo, a doença, o contexto e as estatísticas. Sem esses fundamentos, até mesmo a concepção de Medicina Baseada em Evidências (MBE) poderia ser interpretada de maneira equivocada ou usada intencionalmente para causar algum mal.

A indústria farmacêutica de pesquisa historicamente vem sendo alvo de críticas da imprensa por sua conduta muitas vezes colocada em xeque. São questionamentos frequentes quanto a possíveis ganhos elevados, falta de compromisso com as sociedades locais, altos preços dos produtos, defesa intransigente do direito de propriedade e forte poder de concentração de mercado.

De fato, a partir da década de 1990, houve uma tendência à concentração de mercado quando começaram movimentos importantes de fusões e aquisições de empresas globais que precisavam fazer expressivos investimentos em pesquisa e desenvolvimento de novas terapias para enfrentar um futuro ainda mais desafiador como viria a ser comprovado nos anos seguintes, especialmente com relação a determinadas patologias e a sistemas de inovação e de regulação sanitária que colocariam especialistas e autoridades mundiais de saúde em alerta. Como desenvolver inovações disruptivas, se as novidades são cada vez mais raras? Como atender às crescentes exigências de testes regulatórios para comprovar eficácia e segurança das novas tecnologias? Como fazer frente ao exponencial crescimento, por exemplo, dos casos de câncer do mundo sem um investimento em pesquisa de desenvolvimento de novos medicamentos para tratamento da doença que acomete milhões de pessoas todos os anos?
A cada ano, 14 milhões de pessoas desenvolvem câncer no mundo. De acordo com a Organização Mundial da Saúde (OMS), até 2030, serão 26 milhões de pacientes afetados com custos anuais em torno de US\$ 1 trilhão "à economia global, em mortes prematuras, invalidez e custos médicos". No Brasil, o câncer hoje é a segunda causa de morte, superada apenas por doenças cardiovasculares. A expansão dos casos de câncer está relacionada, entre outras razões, ao envelhecimento da população, à mudança do estilo de vida e à poluição.

Nos últimos tempos, o extraordinário avanço das terapias imunológicas no combate a determinados tipos de câncer elevou significativamente o nível de expectativa da medicina na busca pela cura de tumores agressivos a partir de "resultados duradouros em um número significativo de pacientes". Em razão disso, em 2017, pelo segundo ano consecutivo, o relatório anual da American Society of Clinical Oncology (ASCO) elegeu a imunoterapia como o "Avanço do Ano", reconhecendo que a ciência está no caminho certo e os esforços têm sido recompensados com a introdução de novas tecnologias nos sistemas de saúde permitindo a milhões de pessoas maior acesso a tratamentos inovadores.

Ao desbravar um campo praticamente inexplorado do conhecimento científico e tecnológico, os pesquisadores estabelecem novos e sofisticados padrões de investigação em busca de soluções que, inevitavelmente, conduzem à medicina de precisão, personalizando o tratamento de acordo com as características e condições individuais do paciente e o estágio da doença.

A nova fronteira da inovação representará um aumento nos custos da saúde sem que os orçamentos das fontes pagadoras consigam acompanhar o ritmo desse crescimento. A indústria tem consciência de que terá que promover esforços para evidenciar e melhor atribuir valor ao que desenvolve por meio de processos de avaliação de tecnologias em saúde cujos critérios nem sempre levam em conta as questões sociais. Seja como for, o acesso é mais um desafio posto no centro do debate que mobiliza e preocupa não apenas as autoridades de saúde, mas outros atores importantes como a própria indústria de inovação e, claro, a mídia. Hoje, a imprensa tem desempenhado papel fundamental na cobertura de acontecimentos relevantes do cotidiano das pessoas que clamam por um sistema de saúde acessível e digno, além de denunciar com propriedade as mazelas das redes de atendimento e assistência pelo país. Ao mesmo tempo demonstra uma preocupação com fatos extraordinários como o movimento antivacinas dando alertas para os riscos à saúde, principalmente para as nossas crianças. Alguns veículos, inclusive, conseguem equilibrar o noticiário que prioriza, por exemplo, a defesa do consumidor e informações científicas que sempre surgem como um fio de esperança para pacientes necessitados em meio a tantas aflições.

Esse é o lado positivo do trabalho da imprensa, que deve ser reconhecido. Entretanto, dominar e traduzir com fideli- 
dade para o público consumidor a vastidão do universo que envolve um sistema de saúde e temas ainda mais específicos como acesso, inovação tecnológica, ciência, conhecimento, economia da saúde, judicialização e a complexidade dos sistemas regulatórios deveria servir como um novo estímulo ao profissional de imprensa. A especialização pode levar o profissional a entender, na essência, a dinâmica do setor de saúde e inovação a partir de uma visão racional e sem preconceitos.

Se atuasse como um investigador científico na apuração das matérias, o jornalista apuraria, estudaria, comprovaria e se aprofundaria nos temas como se a redação fosse um laboratório de pesquisa. Seria como lançar mão de uma das raízes da fórmula consagrada do jornalismo, a empatia, mencionada anteriormente, colocando-se no lugar de quem produz inovação. Sem aplicar ciência na produção de notícia, a tendência é permanecer na superfície da versão oficiosa dos fatos.

Há uma deliberada incompreensão da parte da imprensa com relação a certos segmentos do setor de saúde, reforçada pela percepção de que o interesse econômico estaria sempre à frente da necessidade do consumidor, sem qualquer possibilidade de contribuição, solução ou sugestão de melhoria do sistema de saúde e das condições de vida do paciente. Da mesma forma, a imprensa é vista por determinados segmentos privados da saúde como pouco especializada e, por vezes, enviesada, dando preferência às informações negativas, motivada por razões também econômicas: vender notícia impactante. Os pontos positivos de ambos - mídia e organizações privadas de saúde - permanecem ocultos pela distância entre os dois e pela falta de diálogo baseado em ética e transparência.
No filme Mil Vezes Boa Noite, a talentosa e bela atriz Juliette Binoche interpreta a personagem Rebbeca, uma fotógrafa profissional reconhecida no mundo inteiro por ter se especializado na cobertura de zonas de conflito. Na cena inicial, Rebbeca está na Ásia Central, mais precisamente num vilarejo do Afeganistão onde suas lentes precisas e sensíveis registram o ritual desolador: um cinturão de explosivos está sendo atado ao corpo de uma adolescente por senhoras da comunidade, incluindo a própria mãe.

A adolescente tem a missão de se explodir diante do inimigo e Rebbeca acompanha o ato terrorista até o instante final da explosão. A cena não impede a fotógrafa de se aproximar e registrar detalhes da tragédia com tal perfeição que, mais tarde, receberia críticas por estar "glamourizando" o caos. Em suma, o filme trata do dilema ético que eventualmente um jornalista possa viver diante de determinadas situações. Afinal, qual é o limite da atuação de um jornalista para obter o melhor ângulo, a melhor cena, a melhor reportagem?

Fora de questão discutir cerceamento de liberdade e de livre expressão jornalística, sua autonomia e independência, inerentes ao próprio Estado Democrático de Direito e a outros valores constitucionais fundamentais. Nos Estados Unidos, o jornalismo é protegido pela cláusula de liberdade de imprensa na Primeira Emenda Constitucional. Portanto, objetivamente, o propósito é contribuir para o diálogo, reconhecer que sem imprensa livre não há democracia, mas, ao mesmo tempo, a ideia é provocar uma reflexão sobre responsabilidades e o importante papel desempenhado pelo jornalista neste beligerante mundo moderno que invariavelmente confronta organizações privadas de saúde e seus observadores sociais. 